\title{
A bizalom kultúrájának próbatétele A fizikai és lelki egészség, továbbá a társas kapcsolatok és a szubjektív anyagi helyzet összefüggései a bizalommal járványidőszakban
}

\author{
The culture of trust is on trial. \\ Links among physical and mental health, social relations, \\ subjective welfare and trust during pandemic
}

\author{
GRÜNHUT ZOLTÁN, BODOR ÁKOS
}

GRÜNHUT Zoltán: tudományos munkatárs, Közgazdaság- és Regionális Tudományi Kutatóközpont, Regionális Kutatások Intézete; 7621 Pécs, Papnövelde u. 22.; grunhut@rkk.hu; https://orcid.org/0000-0001-6399-4274

BODOR Ákos: tudományos munkatárs, Közgazdaság- és Regionális Tudományi Kutatóközpont, Regionális Kutatások Intézete; 7621 Pécs, Papnövelde u. 22.; bodor@rkk.hu; https://orcid.org/0000-0002-5317-8561

KULCSSZAVAK: bizalom és bizalom kultúrája; koronavírus; European Social Survey

ABSZTRAKT: A tanulmány kiindulópontja az, hogy a koronavírus miatti járvány és intézkedések fokozottan érinthették azokat, akik már a krízisperiódus előtt is fizikai/lelki egészségi problémákkal küzdöttek, társas kapcsolataikat tekintve elszigeteltek voltak, és/vagy az anyagi lehetőségeik tükrében megélhetési nehézségekkel birkóztak. Az ezen élethelyzetetekben lévők okkal tekinthetők veszélyeztetetteknek, különösen egy olyan járványidőszakban, amely az említett nehézségeket fokozza. Evidencia, hogy ezen élethelyzetek megterhelőek az egyének számára, miként az is könnyen belátható: a nevezett problémákkal küzdők társadalmi szintủ aránya hatással van az adott ország kilátásaira. Ez az egyéni és társadalmi hatás természetesen értelmezhető közvetlenül, de megragadható úgy is, mint ami befolyásolja az egyén bizalmát, társadalmi szinten a bizalom kultúráját.

Kézenfekvő annak a magyarázata, hogy miért a bizalmat kívánja a nevezett problémákkal összefüggésbe hozni a tanulmány: a fizikai és lelki egészség, a társas kapcsolatok, illetve az anyagi boldogulás terén mutatkozó egyéni nehézségek káros hatással vannak a társadalmi együttélés szövetére, holott éppen igényelnék azt, mint a segítő támogatás alapját. Ezen elméleti feltételezést teszi megragadhatóvá a bizalom fogalma, egész pontosan Sztompka érvelése a bizalom kultúrájáról, amely koncepciót felhasználva empirikusan is vizsgálható kérdéseket kapunk. A tanulmányban közölt eredmények megerősítik, hogy a nevezett kedvezőtlen élethelyzetek valóban aláássák az egyén bizalmát, miközben az is világosan kiderül: azon társadalmakban, ahol magas az ilyesféle problémáktól érintettek aránya, ott alacsonyabb a bizalom szintje.

Noha az elméleti összefüggések igazolására használt adatok még a járvány előtti időszakból valók, ám a tanulmány okfejtése alapján bizonyosan állíthatjuk: ha közben növekedett a veszélyeztetettek száma, e tendencia mindenképpen káros hatással van az egyén bizalmán túl a megfelelő társadalmi müködéshez szükséges bizalom kultúrájára is.

Zoltán GRÜNHUT: research fellow, Institute for Regional Studies, Centre for Economic and Regional Studies; Papnövelde u. 22., H-7621 Pécs, Hungary; grunhut@rkk.hu; https://orcid.org/0000-0001-6399-4274

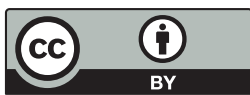


Ákos BODOR: research fellow, Institute for Regional Studies, Centre for Economic and Regional Studies; Papnövelde u.22., H-7621 Pécs, Hungary; bodor@rkk.hu; https://orcid.org/0000-0002-5317-8561

KEYWORDS: trust and the culture of trust; coronavirus; European Social Survey

ABSTRACT: The paper identifies four interrelated dimensions that can describe the status of being seriously impacted by the SARS-CoV-2 (commonly called as the coronavirus) pandemic and its complex consequences. These dimensions are physical health, mental health, social relations, and subjective welfare. The study argues that people who had to face hardships regarding their existential conditions already before the pandemic, were particularly 'harmed' by pandemic measures. While this unfavourable status means diverse individual problems, distresses, and sufferings, the paper claims that the number of 'harmed' people in a given society also affects the prospects of that specific country. Therefore, both micro and macro aspects should be considered, or even more, they need to be linked in order to better grasp their interdependence.

The paper addresses this theoretical task by invoking the conceptual framework of Piotr Sztompka about trust. In his book, Sztompka outlines the multilevel, agent-structure framed, and circularly linked constellation of the social becoming of trust. This dynamic process is about the way micro level (individual) trust dispositions and traits as well as trust capitals contribute to the culture of trust (or distrust) as a macro phenomenon. Circularity is relevant since the culture of trust (or distrust) as a social pattern or reference is always reflected in the structural backgrounds that shape the agents' trust components.

Through Sztompka's theoretical lens it is possible to adequately integrate the aforementioned dimensions of being 'harmed' into this micro-macro constellation, and propose empirically relevant questions like: (1) how these unfavourable individual existential states influence the given subjects' trust?; and (2) how the number of 'harmed' people in a society has an effect on the culture of trust?

The paper inquires these questions by diverse statistical methods on data obtained from the European Social Survey. Concluding results suggest that: (1) people who have hardships with their physical/mental health, live in social isolation, and/or deal with serious income problems, their trust towards others is much more constrained; (2) in countries with relevant number of 'harmed' people the culture of trust is weak and vulnerable, struggles with many dysfunctional dynamics and mechanisms; (3) in countries that the culture of distrust pervades 'unharmed' people are also more distrustful.

\section{Bevezetés}

A SARS-CoV-2 (koronavírus) okozta pandémiát az Egészségügyi Világszervezet (WHO) 2020. március 11-én nyilvánította világjárvánnyá. Globális szétterjedése az elmúlt évtizedek legsúlyosabb egészségügyi kihívásává fajult. Az egyes országokban tömeges szintü megbetegedéseken és elhalálozásokon túl, a járvány, illetőleg annak megelőzése, kezelése mindenütt szigorú intézkedéseket hozott magával: kijárási korlátozásokat, határzárakat, különböző tiltó szabályozásokat a társas érintkezésekkel, csoportos rendezvényekkel, iskolába és munkába járással, szabadidőtöltéssel kapcsolatban. E prevenciós célú intézkedések következtében számos szektor tulajdonképpen leállt, általános gazdasági (termelési és fogyasztási) recessziót, munkanélküliséget, s inflációt kiváltva. Szinte minden országban megnövekedtek az államháztartási kiadások, a folyó költségvetésekben átcsoportosításokat kellett végrehajtani, miközben a bevételek visszaestek. Mindezek mi- 
att, noha az életvédelem a legfontosabb feladat a járványidőszak során, mégis indokolt a negatív hatásoknak való kitettséget átfogóbban értelmezni, hiszen a krízis nem kizárólag egészségügyi természetű. Tanulmányunkkal elsősorban egy ilyesféle feltáró munkához kívánunk hozzájárulni. A veszélyeztetettség négy dimenzióját különböztetjük meg: fizikai egészség, lelki egészség, társas kapcsolatok, szubjektív anyagi helyzet (azaz annak megítélése, hogy a háztartás jövedelméből hogyan lehet boldogulni).

E dimenziók kiválasztása részint önkényes, amennyiben egészen más szempontok mentén is lehetne vizsgálni a járványidőszaki veszélyeztetettséget. Ennek ellenére érdemes figyelembe venni néhány közös aspektust a nevezett dimenziók vonatkozásában. Egyrészt mindegyikre igaz, hogy a járványkonstellációs hatások (vagyis a megbetegedés fenyegetésének terhei és a különböző prevenciós intézkedések kedvezőtlen velejárói) közvetlenül érintik, mégpedig fokozzák e dimenziók jelentőségét. Tehát azok számára, akik kihívásokkal küzdenek fizikai egészségüket, lelki egészségüket, társas kapcsolataikat és/vagy szubjektív anyagi helyzetüket tekintve, a járványidőszak további nehézségekkel súlyosbítja a már amúgy is meglévő problémáikat.

Másrészt a kiválasztott dimenziók, miközben tartalmilag jól elkülöníthető egyéni kihívásokra utalnak, mégis könnyen összekapcsolódhatnak, s generatív módon felerősíthetik egymást valamilyen komplexebb tehertétellé, különösen egy olyan, mindenkit érintő, sokrétű bizonytalanságokat kiváltó vészhelyzetben, mint amilyen a koronavírus miatti világjárvány. Vagyis a veszélyeztetettség négy olyan formájával foglalkozunk alább, amelyek között interrelációs viszony áll fenn: alaphelyzetben egyik sem feltételezi okvetlenül a másikat, de bármelyik tartós és súlyos kibontakozása esetén számot kell vetni a többi felerősödésének kockázatával is.

Harmadrészt mindegyik dimenzió olyan, amelyekkel az érintettek támogatást élvezve könnyebben birkózhatnak meg, mint egyedül. Egy társadalom szűklátókörüségét bizonyítja, ha e kihívásokat pusztán individuális problémákként fogja fel. A fizikai egészség, a lelki egészség, a társas kapcsolatok és/vagy a szubjektív anyagi helyzet tekintetében jelentős kihívásokkal küzdő egyének magas aránya egy adott társadalomban arra utal, hogy az embertársi összetartozás mély törésektől terhes. Egy ilyen társadalomban nemcsak a fokozottan veszélyeztetett egyéneknek nehezebbek a mindennapjaik járványidőszakban, de általában a teljes közösség kilábalási esélyei is rosszabbak, mivel az összetartozás további sérülésének eshetősége aláassa a regeneráció eredményességét. Azaz a négy kiválasztott dimenziónk egyaránt olyan tartalmakra reflektálnak, amelyeket kapcsolatba lehet hozni a társadalmi összetartozással. Ezt a feltételezett összefüggést Piotr Sztompka (1999) elmélete, a bizalom kultúrája alapján fogjuk egyrészt tartalmilag kibontani, másrészt empirikusan vizsgálni.

Írásunk felépítését illetően a következőket érdemes előrebocsátani: először áttekintjük a veszélyeztetettség négy dimenzióját és értelmezzük azok jelentés- 
tartományait. Ezt követően kísérletet teszünk e dimenziók elméleti elhelyezésére Sztompka modelljében. A bizalom kultúráját a társadalmi összetartozás szempontjából fogjuk értelmezni. Az érdekel tehát minket, hogy milyenek az embertársak egymás közötti viszonyrendszerei, mi mondható el az emberek politikai-közéleti részvételi hajlandóságáról és aktivitásáról, továbbá mennyiben toleránsak és szolidárisak a mássággal. Sztompkával egyetértve úgy gondoljuk, hogy a veszélyeztetettség dimenziói, amelyek a lengyel szerző elméleti keretében személyes jellemvonásokként és társadalmi kedélyállapotokként jelennek meg, okai és egyben okozatai is a bizalom kultúrájának (avagy éppen a bizalmatlanság térnyerésének), azaz a társadalmi összetartozás állapotának.

A tanulmány második részében statisztikai elemzésekkel vizsgáljuk a sztompkai modell belső összefüggéseit, illetve kiemelten a veszélyeztetettségnek való kitettséget különböző országokban. Elemzésünk során főként szubjektív mutatókat - egyéni percepciókat - használunk. Az számít tehát, miként jellemzik önmagukat, önnön státuszaikat és állapotaikat az emberek. Adatforrásunk az European Social Survey (ESS) négy, 2012 és 2018 közötti hulláma. Említett forrást elemezve lehetőségünk van országos reprezentatív, nagymintás adatokat vizsgálni, illetve azok tükrében komparatív képet rajzolni. E törekvés nem egyedülálló a hazai tudósközösségben a járványidőszaki nehézségek elemzése szempontjából (lásd Albert, Dávid 2020a,b; Csizmadia, Illéssy 2020; Ferencz 2020; Messing, Ságvári 2020; Messing et al. 2020).

\section{A veszélyeztetettség négy dimenziója}

Az egyén fizikai egészségének állapota, minden kétséget kizáróan, a legadekvátabb veszélyeztetettségi dimenzió a járványterjedés szempontjából. Mivel a koronavírus fenyegetőbb a krónikus betegségekkel küzdő, funkcionálisan károsodott szervezetű emberekre, így okvetlenül fontos képet kapni arról, hogy a lakosság hány százaléka gondolja önmagáról, hogy az egészségi állapota rossz. Lehet, hogy ezen öndiagnózisok nem, vagy csak részben alátámaszthatóak orvosilag, mégis valamilyen módon igazoltak az egyének számára, kifejezik tehát azt, miként gondolkodnak a válaszadók saját egészségük sérülékenységéről, mennyiben bíznak testük ellenálló képességében. Ehhez képest másodlagos, hogy ezen önjellemzések esetleg inkább lelki eredetűek, mint testi tapasztalattal összefüggőek. Akik úgy vélik, hogy egészségi állapotuk rossz, azok mindenképpen veszélyeztetettek abban az értelemben, hogy a kitettségük egészségügyi és/vagy pszichológiai értelemben valós.

A járványidőszaki intézkedéseknek, összevetve a fizikai egészség megóvása érdekében tett erőfeszítésekkel, kevésbé van homlokterében a lelki egészség romlásának megakadályozása. Természetesen a prioritások tükrében ez elfogadható, ugyanakkor nem jelenti azt, hogy a pszichés egyensúly sérülésének veszélye 
nem fokozódna járványidőszakban. A mindenkit érintő testi fenyegetettség, a fizikai távolságtartás előírása, a személyes tér beszűkülése, az egyéni rutinok megváltoztatásának szüksége, a társas érintkezések mérséklődése, az általános bizonytalanság, vagy a gazdasági recesszió - hogy másokat ne is említsünk - egyértelmű kihívást jelentenek az egyén lelki egészségére. Anélkül, hogy részletekbe bocsátkoznánk a mentálhigiéniás sérülések tekintetében, két - kellően absztrahálható - aspektus mindenképpen beszédes. Az egyik a boldogtalanság, az a csalódottságot és kilátástalanságot kifejező, szenvedésteli mentális-emocionális kedélyállapot, amikor már nem az öröm, a jókedv, a pozitív élmények és tapasztalatok hiánya, vagy az ezeket beárnyékoló veszteségek, sikertelenségek és szorongások eluralkodása a legfőbb fenyegetés a szubjektumra nézve, hanem a lelki meghasadás terhe, azaz az önalakításról való lemondás eshetősége (Haybron 2000, 2013). Hasonló jelentéstartományban mozog az önelégedetlenség is. Ennek kiváltó oka az, amikor az egyén mind az önbecsülését elveszíti kudarcsorozatok miatt, mind a társas érintkezéseiből leszűrt tapasztalata szerint mások nem ismerik el, nem tartják sokra a személyét és teljesítményeit. Az ilyen élmények elszenvedője hajlamossá válik arra, hogy bent ragadjon a tehetetlenségben, kiégettséget és motiválatlanságot érezzen, a lemondás-feladás örvényébe sodródjon, s saját önképét destruktív módon rombolja (Kekes 1988; Nozick 1989).

A veszélyeztetettség szempontjából beszélni kell a társas kapcsolatokról is, hiszen azokra minden embernek szüksége van, még ha az érintkezések gyakoriságának igénye személyenként változó lehet is. A járványidőszaki intézkedések egyik első lépése volt a társas kapcsolatok korlátozása a fizikai távolságtartás előírásával, illetve az otthonmaradás szorgalmazásával. Ennek hatásait nem szabad lebecsülni, mivel a társas érintkezések során nemcsak érzéseinket, élményeinket, tapasztalatainkat, gondolatainkat osztjuk meg partnereinkkel, szubjektív reflexiók, kritikai észrevételek, esetleg egyszerüen csak a meghallgatva lenni állapot végett, de a másik féllel való interakció során mindig megalkotjuk és újraalkotjuk is magunkat (Jaeggi 2014). Ezt tesszük egyrészt narratív formában azon önkifejezések által, amiket mondunk, amikről véleményt alkotunk, ahogyan elbeszéljük magunkat, illetve a magunk körül észlelt dolgokat, eseményeket, összefüggéseket. Másrészt végezzük ezt performatívan is tetteinkkel, szokásainkkal, rutincselekvéseinkkel, külső megjelenésünkkel, magatartásainkkal (Cavell 1976). Társas kapcsolatokra van tehát szükség ahhoz, hogy magunk lehessünk; hogy produkálhassuk azon tulajdonságainkat és ismérveinket, amelyeken változtatni szeretnénk, s reprodukálhassuk azokat, amelyeket megőrizni akarunk. A társas kapcsolatok nélkül maradó egyén nemcsak az embertársaihoz való viszonyulásait veszíti el, de az önmagához való reflexív és kritikai hozzáállás kapaszkodóit is (Honneth 2007).

Végezetül a szubjektív anyagi helyzet alatt a háztartás jövedelméből való boldogulás egyéni megítélését értjük. E dimenzió tartalma esetében nemcsak szubjektív vélekedésekre támaszkodunk, hanem elfogadjuk azt is: nem lehet objektív módon megállapítani, mi az a jövedelem, aminek már elégségesnek kell 
lennie egy bizonyos létszámú háztartás számára; vagyis azonos jövedelemből, saját megítélésük szerint, teljesen eltérő módon boldogulhatnak különböző háztartások, azaz bárkinek lehetnek - jövedelmi szintjétől függetlenül - megélhetési nehézségei. Azért alkalmazzuk ezt a tágabb értelmezést, mert álláspontunk szerint, akik úgy vélik, nehezen boldogulnak jövedelmükből, azok számára a járványidőszak - különböző okok miatt (esetleges jövedelemcsökkenés, állásváltás-állásvállalás nehézsége, infláció és drágulás) - fokozott anyagi nehézségeket hozhat. Ennek alapján pedig okkal tarthatjuk őket veszélyeztetettnek.

\section{A bizalom (bizalmatlanság) kultúrája és abban a veszélyeztetettség dimenziói}

Sztompka koncepciója abban az értelemben egyedülálló kísérlet a szociológiai jellegű bizalomelméletek között, hogy két szempontból is szintetizáló szándékú (Bodor, Grünhut 2015). Egyrészt teoretikus leírását kívánja adni a bizalom társadalmivá válásának, vagyis arra ad átfogó magyarázatot, hogy az egyének szintjéről, az egyéni interakciókból kibontakozva miként lesz társadalmi jelenséggé, strukturálisan is kereteket adó viszonyrendszer-elvvé a bizalom (vagy bizalmatlanság). Ebben a bizalom mikro- és makrolencséjü kutatásainak szintetizálását kell felismernünk. Másfelől Sztompka figyelmet fordít modelljében a bizalomkutatás három legfőbb elméleti irányzatának - a racionális döntést követő, a pszichológiai diszpozíciókra összpontosító, valamint a kulturális minták referenciaértékét hangsúlyozó okfejtések - kapcsolódási lehetőségeire is (Grünhut et al. 2019a). Giddens (1984) strukturációs érvelését alapul véve, a bizalom kultúrája tehát egy olyan koncepció, amely minden elemében a humán ágencia és az azt körülölelő intézményi közeg kölcsönhatása során formálódó dinamikákat próbálja beazonosítani egy generatív jelenség - a bizalom (bizalmatlanság) - társadalmivá válásának elméleti leírásához.

Sztompka (1999) az egyes komponenseket lineáris oksági rendbe kapcsolja, azonban a teljes modelljére hangsúlyozottan körkörös kauzalitást fogad el. Ami tehát magyarázza a bizalom kultúráját, azt egy átfogóbb lencsén keresztül nézve magyarázza maga a bizalom kultúrája is. Éppen ezért, amikor a lengyel szerző modellje első elemeként makrotársadalmi strukturális kontextusról értekezik, akkor azt úgy kell elképzelnünk, mint ami ráépül egy történelmi léptékben formálódott kulturális talapzatra: magára a bizalom (bizalmatlanság) kultúrájára. E strukturális tényezőket Sztompka öt csoportba sorolja. Ezek: normatív egység (jog, erkölcs, szokások), stabilitás (intézményi folytonosság, strukturális rend, kiszámítható reformok), átláthatóság (intézmények, intézményi szereplők működésének nyomon követhetősége, információk megismerhetősége), elszámoltathatóság (intézmények, intézményi szereplők felelősségre vonhatósága, változtathatósága), familiaritás (szélesen vett társadalmi közegben - építészet, divat, 
diskurzusrend, közlekedési stílus stb. - érvényesülő megszokottság) (Sztompka 1999, 122-125.).

E strukturális tényezők keretezik, egyúttal megalapozzák a bizalom kultúrája szempontjából releváns egyéni komponenseket. Ezek egyik csoportját Sztompka individuális tőketényezőkként írja le (Sztompka 1999, 126-132.). A bourdieu-i logikát követve azért tőketényezők ezen elemek, mert a társadalmi struktúrán belüli tételérések során előnyökre válthatók. Értelemszerűen, ezen elemeken keresztül integrálja modelljébe a lengyel szerző a racionális döntés bizalomelméleti érvelését. A tőketényezők nyolc típusát különbözteti meg Sztompka (de teoretikusan nem kizárható ezek bővítése). A társadalmi státusz, pozíció, szereppresztízs szempontjából releváns tényezőkről van szó: anyagi jólét, biztos munkahely, társadalmi szerepek pluralitása, hatalom- és befolyásolási képesség, iskolázottság, társas érintkezések szövete, családi közeg, vallásosság.

Ezekhez képest egyéni diszpozícióknak tekinthetők azok az inkább morálisemocionális impulzusú, pszichológiailag releváns személyiségjegyek, amelyek az individuális gondolkodásmódot befolyásoló beállítódásokra reflektálnak Sztompka modelljében (Sztompka 1999, 125-126.). Miközben e komponensek jelentéstartományát csupán körülíróan adja meg a lengyel szerző, egy fontos kritériumot azért rögzít: nevezett egyéni jellemvonások összeolvadnak egy társadalmi kedélyállapottá, amely visszahat az emberek diszpozícióira. Azaz a modell egészére érvényes mikro-makro kölcsönhatás e dimenzió esetében sajátos konstellációs dinamikaként is érvényes. Talán nem hibátlan Sztompka érvelése, abban viszont mindenképpen egyet tudunk vele érteni, hogy az egyéni jellemvonások gyors változásainak eshetőségét akarja kiiktatni a társadalmi kedélyállapot referenciakorlátjával. Ellentétpárokon keresztül azonosítja Sztompka a kérdéses jellemvonásokat: optimizmus/ pesszimizmus, jövőorientáció/hagyománykövetés, magas/alacsony aspirációs szint, aktivitás-/passzivitáshajlam, siker-/alkalmazkodás-orientáció, újításkészség/ konformitás. Ezek befolyásolják tehát az egyéni megismeréseket-gondolkodásmódokat, amelyekből kibontakozik egy mintává váló, s így ugyanezen személyes jellemvonásokra visszaható társadalmi kedélyállapot. Tanulmányunkban ezen elemek tekintetében találjuk kifejezetten illeszkedőnek a veszélyeztetettség dimenzióinak elméleti elhelyezését. Merthogy megítélésünk szerint a fizikai egészség, a lelki egészség, a társas kapcsolatok, s a szubjektív anyagi helyzet okvetlenül jellemvonásbeli és kedélyállapotbeli kifejeződéssel bírnak. Egész pontosan a veszélyeztetettség, vagyis a rossz egészségi állapot, a boldogtalanság/önelégedetlenség, az egyedüllét (társas elszigetelődés), s a nehéz anyagi boldogulás aláássa az optimizmust, a jövőorientációt, a magas aspirációs szintet, az aktivitásra való hajlandóságot, a sikerorientációt, az újítási (kockázatkeresési) kedvet. A veszélyeztetettség tehát egyfajta konkretizálási és operacionalizálási jelentőséggel bír Sztompka modelljével összekapcsolva.

A strukturális és az egyéni tényezők bemutatását követően térhetünk át magára a bizalomra (bizalmatlanságra), ami Sztompka szerint tehát történelmi lép- 
tékủ kulturális talapzatként értelmezhető, s ennek értelmében makrosíkon azonosítható. Ugyanakkor bizalmat (avagy éppen bizalmatlanságot) mindig az adott kulturális-strukturális közegben élő emberek éreznek, azaz mikroszintű relevanciája legalább annyira van a jelenségnek. A bizalom funkcióit (illetve a bizalmatlanság diszfunkcióit) a lengyel szerző éppen ezért egyéni és társadalmi síkon adja meg (Sztompka 1999, 102-118.). Elég számba venni a bizalom hatásait ahhoz, hogy a bizalmatlanság negatív következményeit értsük. Mikrosíkon a bizalom felszabadítja a humán kvalitásokat és kapacitásokat; ösztönzi a kreativitást, az újitást, a kritikai szemléletet; elősegíti az interakciókat, azok tartalmasságát, tartósságát, közvetlenségét, intimitásuk mélyülését. Oldja a gyanakvást és kontrolligényt; támogatja a részvételi kedvet, s fékezi a rutinkövetés fásultságát. Társadalmi funkciói között a bizalom támogatja a mobilitást, a közös gondolkodást, a kollektív felelősségvállalást, a bevonást, a hálózatok bővülését, s az együttműködések érvényesülését. Mérsékli a közönyösséget a társadalmi ügyek vonatkozásában. Segíti a konstruktív vitát, a konszenzuskeresést. Serkenti a szolidaritást, az empátiát, az egyenlőtlenségek elleni fellépést. Előmozdítja a be- és elfogadást, a toleranciát, a pluralizmus minden formáját, a különbözőségek legitimitását. Megszilárdítja az egyén közösséghez tartozását és identitását; ösztönzi a közösségért való áldozatvállalást és az önkéntességet. Egy efféle kulturális talapzatra, az embertársi viszonyrendszerek ilyen jellegü öszszekapcsoló szövetére épülhetnek fel azok a strukturális tényezők, amelyek normatív egységet, stabilitást, átláthatóságot, elszámoltathatóságot és familiaritást adnak, progresszíven hozzájárulva ezzel az egyéni tőketényezőkhöz és jellemvonásokhoz (illetve azokból kibontakozva a társadalmi kedélyállapothoz). Ha pedig a struktúrák és az azokkal kölcsönhatásban cselekvő egyének egymás közötti interakciói bizalomtelítettek, akkor együttesen létrehozzák a bizalom légkörét, azaz reprodukálják magát a bizalom kultúráját.

A bizalmat három fókuszponton keresztül próbáljuk azonosítani, reflektálva a fenti jelentéstartalmakra: embertársak egymás közötti viszonyrendszerei, az emberek politikai-közéleti részvételi hajlandósága és aktivitása (amelyben az intézményi közeghez való viszonyulás mutatkozik meg), valamint a másság iránti nyitottság (az énből kivetített imaginárius Mi helyett, az éntől különböző Másik elfogadása). Az embertársak közötti viszonyrendszert az ún. „bizalomskálával” mérjük (Uslaner 2002). Ez az eszköz három aspektusra utal: megbízhatóság, tisztességesség, segítőkészség. A három együtt túlmutat a viszonyrendszer pusztán instrumentális-racionális eshetőségén, amennyiben a tisztességesség és segítökészség mindenképpen emocionális-morális viszonyulást feltételez (lásd Grünhut et al. 2019a, b).

A politikai-közéleti részvétel reflektál mind az embertársakhoz, mind az intézményekhez való viszonyulásra, azaz magára a strukturációs konstellációra. A részvétel két szinten érthető meg: egyfelől ismerni kell a hajlandóságot, másrészt magát az aktivitási dinamikát. A hajlandóságra utal a politikai hatékonyságérzet 
(political efficacy), ami kifejezi az egyén közpolitikák (policies), politikai hatalomgyakorlás (politics), továbbá politikai intézményközeg (polity) iránti bizalmát, illetve az azzal kapcsolatos vélekedéseit: mennyiben látja magát képesnek a politikai folyamatok befolyásolására (struktúra és ágencia relációjának megítélése) (Sulitzeanu-Kenan, Halperin 2013). Ha az egyénnek erősebb a politikai hatékonyságérzete, akkor magasabb a hajlandósága a részvételre. Az aktivitások végrehajtása tehát előfeltételez valamilyen intencióébresztő hajlandóságot.

Végezetül a másság iránti nyitottság lencséjén keresztül azt akarjuk vizsgálati szemponttá tenni, hogy az egyének bizalomérzete valóban rendelkezik-e az univerzalitás kritériumával, azaz képes meghaladni az azonosság korlátait, s elfogadni a Másikat. E reflexív és kritikai jellegü progresszivitás elengedhetetlen ahhoz, hogy az egyén felszabadítsa embertársaival meglévő viszonyrendszereit a (kulturális-tradicionális, haszonmaximalizáló racionális, vagy egyéb sémaszerü) referenciakényszerek alól, s segítse ezzel a saját - egyedi és egyszeri - szubjektivitása kibontakozását. A másság elfogadásával, a Másik irányában tett bizalommutatással az egyén ugyanis bővíti azt az elméleti teret, amelyen belül önmagát konstituálhatja (Brons 2015).

\section{Adatok és eredmények}

Elméleti okfejtéseink empirikus alátámasztásaként a következőkben azt vizsgáljuk meg, hogy a sztompkai keretben elhelyezett veszélyeztetettségi dimenziók, valamint különböző egyéni tőketényezők milyen összefüggést mutatnak a bizalom megragadásához használt tartalmakkal (vagyis az embertársak egymás közötti viszonyrendszereivel, a politikai-közéleti részvételi hajlandósággal és aktivitással, továbbá a másság iránti nyitottsággal). Ezt lineáris regressziós modellekkel vizsgáljuk. E modellek függő változóit a bizalomtartalmak adják, míg a magyarázó változók sora mindegyik modellben ugyanaz: a veszélyeztetettségi dimenziók, valamint különböző egyéni tőketényezők [itt szükséges megjegyezni: a tőketényezők között elsősorban szociodemográfiai változókat vonunk be, ami Sztompka érvelésétől nem idegen, s az átfogóbb szakirodalomban is e mutatókat releváns, a bizalom szintjét befolyásolni képes tényezőkként veszik számba (lásd Uslaner 2002)]. A modell-számítások előtt két információközlést szükséges megtenni a pontos interpretáció végett: egyrészt a méréshez használt változóinkat indokolt kifejteni (1. táblázat), másrészt e változók leíró statisztikai adatait bemutatni (2. táblázat). 
1. táblázat: A felhasznált változók, illetve egyes esetekben azok újrakódolása Variables used in the study, and their recoding in certain cases

Veszélyeztetettség dimenziói

Fizikai egészség Felhasznált változó: „Milyen az Ön általános egészségi állapota?” A kérdőívben öt válaszlehetőség állt a megkérdezettek rendelkezésére: 1 - nagyon jó; 2 - jó; 3 kielégítő; 4- rossz; 5 -nagyon rossz. A válaszokat úgy kódoltukújra, hogy egyrészt megfordítottuk a skálairányt, vagyis az alacsony értékek a minél rosszabb egészségi állapotot jelölik, míg a magasak a jobbat. Másrészt az elemzés második szakaszában egy kétkategóriás változót hoztunk létre úgy, hogy az egészségügyi állapotukat jónak, de legalább kielégítőnek itélóket (az eredeti kódolás szerinti 1es, 2-es és 3-as opciókat választókat) elkülönítettük a saját egészségügyi állapotukról egyértelműen negatívan nyilatkozóktól (4-es és 5-ös alternatívákat jelölóktől). A veszélyeztetettség szempontjából csak az utóbbiakat szürtük ki.

Lelkiegészség

Társas kapcsolatok

Szubjektív anyagi helyzet A boldogtalanság (,Mindent egybevetve, mennyire érzi magát boldognak?”) és az önelégedetlenség („Mindent összevetve mennyire elégedett mostani életével?”) méréséhez is egy-egy változót használtunk. Mindkettő 0-10-es 11 fokú skálát kínál a válaszadáshoz, ahol a 0 jelentése az „nagyon boldogtalan/elégedetlen”, míg 10-é pedig „nagyon boldog/elégedett”. A lelki egészség esetében használt adatunk e két változó összevont, átlagolt értékébool állt össze. Az elemzés második szakaszában a válaszokat úgy kódoltuk újra, hogy a legfeljebb 4-es értéket jelölóket tekintettük a lelki egészség szempontjából veszélyeztetettnek.

A társas kapcsolatok hiányát, vagyis az egyedüllétet a következő változóval mértük: „Milyen gyakran el társasági életet, jár össze, barátaival, rokonaival vagy kollégáival?" A megkérdezettek számára hét válaszlehetőség nyît: 1 - soha; 2 ritkábban, mint havonta egyszer; 3 - havonta egyszer; 4 - havonta többször is; 5 hetente egyszer; 6 - hetente többször is; 7 - minden nap. Az elemzés második részében a válaszokat úgy kódoltuk újra, hogy az 1-est jelölóket kiszürtük, mint azokat, akik egyáltalán nem élnek társasági életet. Őket tekintjük veszélyeztetettnek.

Felhasznált változó: „Melyikleírásközelíti meg leginkább azÖnök háztartásánakjelenlegi jövedelmi helyzetét?" A válaszadásra négy alternatívát kínál a kérdőív: 1 kényelmesen megélünk a jelenlegi jövedelmünkből; 2 - kijövünk a jelenlegi jövedelmünkből; 3 - nehezen élünk meg a jelenlegi jövedelmünkből; 4 - nagyon nehezen élünk meg a jelenlegi jövedelmünkből. A válaszokat úgy kódoltuk újra, hogy egyrészt megfordítottuk a skála irányát, vagyis az alacsony értékek a minél rosszabb megélt anyagi helyzetet jelölik, míg a magasak a jobbat. Másrészt az elemzés második szakaszában egy két kategóriábólálló változót hoztunk létre: 1es és 2-es opciók - boldogulnak a jövedelmükből; 3-as és 4-es válaszalternatívák nehezen boldogulnak ajövedelmükből. Veszélyeztetettnek azokat tekintjük, akik úgy vélekednek, nehezen boldogulnak ajövedelmükből. 
Életkor

Iskolai végzettség

Lakóhely

Vallásosság
Születési évből számított életkor

Hármas bontás: 1) legfeljebb általános iskolai végzettségü; 2) középfokú végzettségü; 3) felsőfokú végzettségü

Lakóhely tekintetében azt a változót használtuk, amely a válaszadóra bízza annak eldöntését, hogy a saját lakóhelyét jellege szerint besorolja. Ehhez a szubjektív kategorizáláshoz hat alternatívát kínál a kérdőiv, amelyeket mi három válaszcsoportba vontunk össze: 1) nagyváros vagy nagyváros elővárosa; 2) város vagy kisváros;3) falu vagy tanya.

Felhasznált változó: „Függetlenül attól, hogy Ön tartozik-e valamelyik egyházhoz vagy felekezethez, mennyire tartja vallásosnak magát? A kérdésre egy 0-tól 10-ig terjedő skála segítségével lehet válaszolni, ahol a 0 azt jelenti, hogy „egyáltalán nem vallásos”, míg a 10 azt, hogy „nagyon vallásos”.

\section{Bizalomtartalmak}

Embertársak egymás közötti viszonyrendszerei

Politikai-közéleti részvételi hajlandóság (és képesség)
E bizalomtartalomhoz az ún. bizalomskálát használtuk, ami három kérdoívelemből áll. A feltett kérdésekre a válaszadók egy 11 fokú, 0-10-es skála használatával tudtak felelni. A bizalomskála kérdései a következők:

- „Általánosságban Ön mit mondana? A legtöbb emberben meg lehet bízni, vagy inkább azt, hogy nem lehetünk elég óvatosak az emberi kapcsolatokban?” ( 0 - „Nem lehetünk elég óvatosak”; 10 - „A legtöbb ember megbízható”)

- „Gondolja, hogy a legtöbb ember megpróbálná kihasználni Önt, ha alkalma nyilna rá, vagy igyekeznének tisztességesek lenni?” (0 - „A legtöbb ember megpróbálná kihasználni”; 10 - „A legtöbb ember igyekezne tisztességes lenni”)

• „Ön szerint az emberek inkább csak magukkal törődnek, vagy általában segitókészek?” (0 - „Az emberek csak magukkal törődnek”; 10 - „Az emberek általában segítókészek")

Az embertársak közötti viszonyrendszert e három kérdésre adott válaszok átlagával mértük.

E bizalomtartalom méréséhez négy változót használtunk: 1) „Véleménye szerint [országban] a politikai rendszer mennyire teszi lehetövé, hogy az Önhöz hasonló emberek beleszóljanak abba, hogy a kormány mit csinál?" (1 - egyáltalán nem; 2 - nagyon kevéssé; 3 - valamennyire; 4 - nagyon; 5 - teljes mértékben); 2) „Érzése szerint mennyire képes Ön arra, hogy aktív szerepet vállaljon egy politikai kérdésekkel foglalkozó csoportosulásban?" (1 - egyáltalán nem képes; 2 - kevéssé képes; 3 - többékevésbé képes; 4 - többnyire képes; 5 - teljes mértékben képes); 3) „És Ön szerint a politikai rendszer milyen mértékben teszi lehetövé, hogy az Önhöz hasonló emberek befolyásolják a politikát?" (1 - egyáltalán nem; 2 - nagyon kevéssé; 3 valamennyire; 4 - nagyon; 5 - teljes mértékben); 4) „És mennyire bízik abban, hogy a saját képességei lehetơvéteszik, hogy részt vegyen a politikában?" (1 - egyáltalán nem bízik; 2 - egy kicsit bízik; 3 - eléggé bízik; 4 - nagyon bízik; 5 - teljes mértékben bízik benne). Az e négy kérdésre adott válaszok átlagát használjuk a politikaiközéleti hajlandóság megragadásához. E bizalomtartalom esetében kisebb elemszámú minta áll rendelkezésünkre, mivel ezt a kérdésblokkot az ESS csak a 8. hullámtól kezdte alkalmazni. 
Politikai-közéleti

részvételi aktivitás

Másság iránti nyitottság 1 (migráció)

Másság iránti nyitottság 2 (melegek és leszbikusok)
Felhasznált kérdésblokk: „Különböző módokon lehet megakadályozni a problémák kialakulását, és javitani a dolgokon. Az elmúlt 12 hónap során elófordult, hogy Ön a következö dolgok valamelyikét tette? Tehát elófordult, hogy" 1) kapcsolatba lépett politikussal, kormányzati, vagy önkormányzati képviselővel? 2) tevékenykedett politikai pártban vagy más politikai szervezetben? 3) részt vett más szervezet vagy egyesület munkájában? 4) viselt, vagy kihelyezett választási kampányjelvényeket/jelképeket? 5) tiltakozó levelet, nyilatkozatot írt alá? 6) részt vett törvényes, nyilvános felvonuláson? 7) szándékosan nem vásárolt, bojkottált bizonyos termékeket? A válaszlehetőség mindegyik kérdőív-elem esetében igen/nem. A válaszok egyszerü összegzésével hoztuk létre a politikaiközéleti aktivitását mérő változót.

A felhasznált két változó (a kérdések szövegezése az egyes országokhoz igazított): 1) „A külföldön elő nem magyar nemzetiségüek mekkora részének engedné mega betelepülést?” 2) „Az Európán kívüli szegényebb országokban elo” emberekmekkora részének kellene megengedni, hogy Magyarországra jöjön élni?" (mindkét kérdés esetében a felkínált válaszlehetőségek: 1 - sokuknak meg kellene engedni, hogy Magyarországra jöjjenek élni; 2 - jó néhányuknak meg kellene engedni; 3 keveseknek kellene megengedni; 4 - senkinek nem kellene megengedni). A válaszok újrakódolása során megfordítottuk a skálairányt, vagyis az alacsony értékek az elutasítást jelölik, míg a magasak a befogadást. A két változó átlagát használjuk az elemzésben.

Felhasznált változó: „Mennyire ért egyet a következő kijelentéssel? Hagyni kellene, hogy a meleg férfiak és a leszbikus nók szabadon éjeék az életüket melegként és leszbikusként úgy, ahogy a karják." (1 - teljesen egyetértek; 2 - egyetértek; 3 - egyet is értek, meg nem is; 4 - nem értek egyet; 5 - egyáltalán nem értek egyet). Az elemzés során a skála értékeit megfordítottuk úgy, hogy a magasabb értékek jelöljék a nagyobb egyetértést a kijelentéssel. 


\begin{tabular}{|c|c|c|c|c|c|}
\hline \multicolumn{6}{|c|}{$\begin{array}{c}\text { 2. táblázat: Leíró statisztikák } \\
\text { Descriptive statistics }\end{array}$} \\
\hline & N & Átlag & Szórás & Skála & $\begin{array}{l}\text { Cronbach } \\
\text { alfa }\end{array}$ \\
\hline \multicolumn{6}{|l|}{ Veszélyeztetettség dimenzióia } \\
\hline Fizikai egészség & 188922 & 3,67 & 0,92 & $1-5$ & - \\
\hline Lelki egészség & 189040 & 6,94 & 2,01 & $0-10$ & 0,81 \\
\hline Társas kapcsolatok & 187871 & 4,81 & 1,61 & $0-7$ & - \\
\hline Szubjektív anyagi helyzet & 186946 & 2,88 & 0,88 & $1-4$ & - \\
\hline \multirow{2}{*}{\multicolumn{6}{|c|}{$\begin{array}{l}\text { Egyéb tőketényezók (részint } \\
\text { szociodemográfiai kontrollváltozók is) }\end{array}$}} \\
\hline & & & & & \\
\hline Életkor & 188686 & 46,56 & 18,78 & $15-114$ & - \\
\hline Iskolai végzettség & 188119 & - & - & $1-3$ & - \\
\hline Lakóhely & 188821 & - & - & $1-3$ & - \\
\hline Vallásosság & 187402 & 4,55 & 3,03 & $0-10$ & - \\
\hline \multicolumn{6}{|l|}{ Bizalomtartalmak } \\
\hline $\begin{array}{l}\text { Embertársak egymás közötti } \\
\text { viszonyrendszerei }\end{array}$ & 189030 & 5,02 & 1,88 & $0-10$ & 0,73 \\
\hline $\begin{array}{l}\text { Politikai-közéleti részvételi hajlandóság } \\
\text { (és képesség) }\end{array}$ & 44202 & 2,07 & 0,77 & $1-5$ & 0,78 \\
\hline Politikai-közéleti részvételi aktivitás & 183192 & 0,82 & 1,28 & $0-7$ & - \\
\hline Másság iránti nyitottság 1. (migráció) & 184235 & 2,49 & 0,88 & $1-4$ & 0,88 \\
\hline $\begin{array}{l}\text { Másság iránti nyitottság 2. (melegek és } \\
\text { leszbikusok) }\end{array}$ & 181077 & 3,70 & 1,31 & $1-5$ & - \\
\hline
\end{tabular}

Megjegyzés: a számitások kombinált súlyok (post-stratification x population size) használatával történtek Forrás: szerzői szerkesztés az ESS 5-8 hullámok adatelemzése alapján

\section{Veszélyeztetettség dimenziói}

A regressziós elemzéseket mindegyik modell esetében két lépésben hajtottuk végre. Elsőként az életkor, az iskolai végzettség, a lakóhely típusa és a vallásosság hatását vizsgáltuk az egyes bizalomtartalmakra, majd második lépésként kibővítettük a modell magyarázó változóinak körét a veszélyeztetettség dimenzióival. A 3. táblázat a regressziós elemzés eredményeit mutatja be.

Az egyes modellekhez tartozó $R^{2}$ értékeket figyelembe véve, számunka legfontosabb annak a megállapítása, hogy a második lépésben beléptetett veszélyeztetettségi dimenziók jelentősen javítanak mindegyik modell magyarázóerején. Ezzel empirikusan is igazolni tudjuk azt az eddig elméleti szinten megállapított összefüggést, miszerint a veszélyeztetettség különböző állapotai hatással vannak a bizalomra; ráadásul mindez akkor is igaz, ha olyan szociodemográfiai (a sztompkai modellben egyéni tőketényezőként értelmezett) változók, mint az életkor, az iskolai végzettség, a lakóhely típusa vagy a vallásosság hatását kiszűrjük. A stan- 


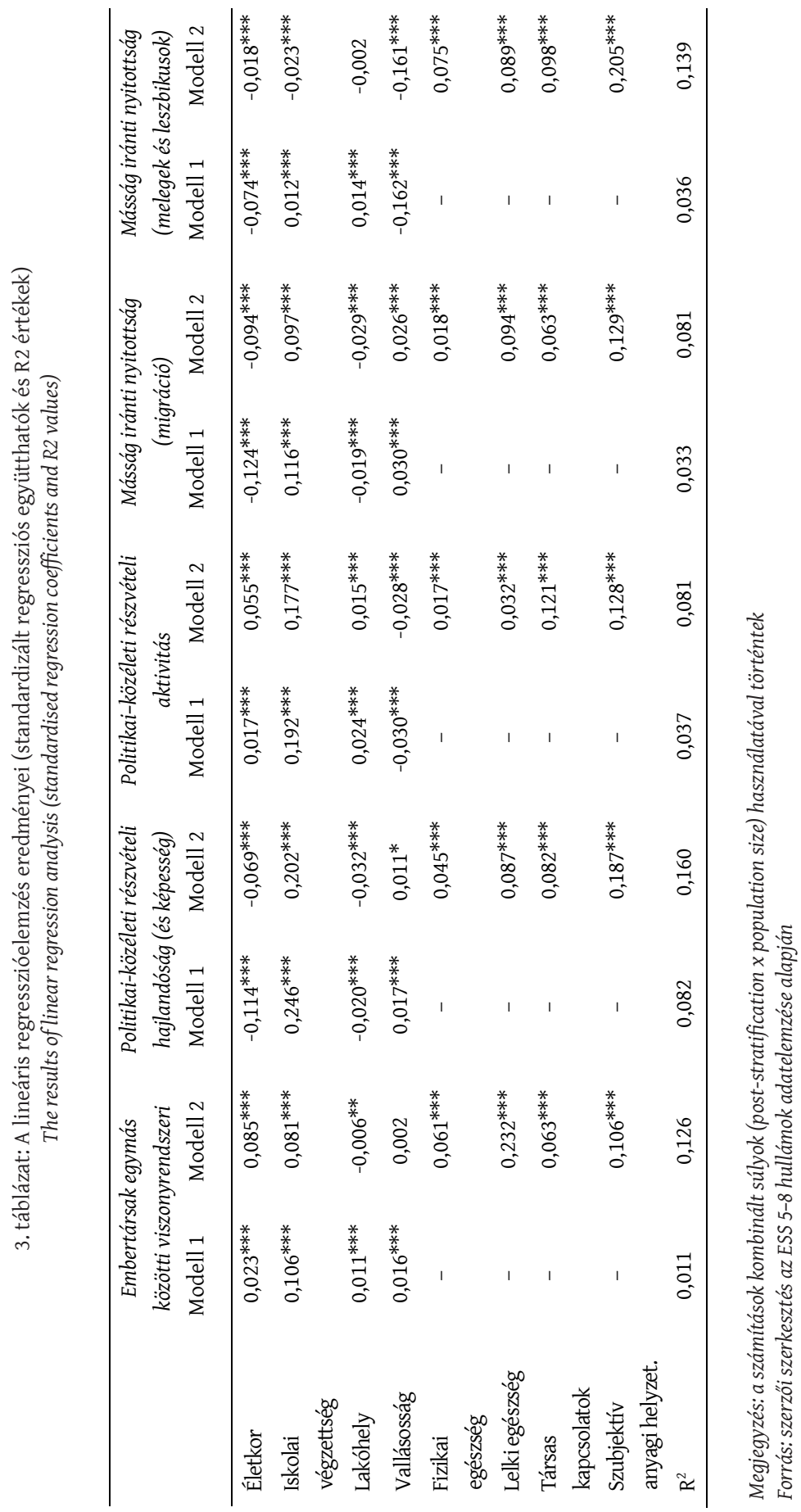


dardizált regressziós együtthatók értékeit tekintve a következő lényeges észrevételeket tehetjük: a fizikai és a lelki egészség egyéni megítélésének javulásával, a társas kapcsolatok intenzitásának fokozódásával, továbbá a szubjektív anyagi helyzet érzetének pozitívabb értékelésével kedvezőbbé válnak az ismeretlen embertársakról vallott képzettek, fokozódik a politikai-közéleti jellegű részvételi hajlandóság és aktivitás, illetve erősödik a másság iránti nyitottság - azaz: inkább kibontakozik a bizalomérzet. Másként megfogalmazva ugyanezt: elmondható, hogy a veszélyeztetettség dimenziónak kedvezőtlen állapotai (vagyis a rossz fizikai és lelki egészség, a társas kapcsolatok hiánya, és a nehéz anyagi boldogulás) erősítik a bizalmatlanságot. Az egyes tényezők hatását tekintve megállapítható továbbá, hogy a szubjektív anyagi helyzet mindegyik függő változóra relatíve erős hatást gyakorol, a modellek egy részénél ez igaz a lelki egészségre és a társas kapcsolatokra is, míg a fizikai egészség - a többi veszélyeztetettségi dimenzióhoz képest - inkább szerényebben befolyásolja a bizalom változóit.

\section{A veszélyeztetettség és a bizalom területi különbségei}

Az empirikus elemzés során eddig egyéni szinten vizsgáltuk a veszélyeztetettség dimenzióit, az egyéb tőketényezőket és a bizalomtartalmakat, illetve mindezek összefüggéseit. Elméleti érvelésünk szerint ugyanakkor alapvető jelentőségü látni azt is, a veszélyeztetettség makroszintű felhalmozódása (vagyis azon emberek aránya, akik e nehézségekkel küzdenek) miként alakul az egyes országokban. E kedvezőtlen társadalmi jelenségek ugyanis negatívan befolyásolhatják a bizalom kultúráját: ahol magas a veszélyeztetettek aránya, ott a nem-veszélyeztetettek is inkább a bizalmatlanság légkörében élnek, mivel az embertársi összetartozás gyenge és sérülékeny. Ennek megfelelően, a 4. táblázat a veszélyeztetettség négy dimenziója szerint közli, hogy adott országokban a lakosság mekkora aránya küzd e nehézségekkel. A táblázatban szerepel egy kompozit indikátor is, ami azt mutatja, hogy a lakosság hány százaléka veszélyeztetett legalább egy dimenzió szerint.

A 4. táblázat adatairól könnyen leolvasható, hogy Európa országaiban komoly különbségek mutathatók ki a tanulmány által vizsgált veszélyeztetettségi dimenziók tekintetében. Magyarország helyzete mindegyik dimenzió esetében kedvezőtlen, de szembeötlően rossz a társas kapcsolatok terén: a vizsgált országok között messze nálunk élnek a legtöbben, a lakosság csaknem egytizede, teljes elszigeteltségben. Amennyiben a kompozit indikátor alapján hasonlítjuk össze az adatbázisban található országokat, akkor egyrészt azt kell megállapítanunk, hogy Magyarországon a lakosság több mint fele veszélyeztetettnek tekintheto", tehát legalább az egyik veszélyeztetettségi dimenzióban érintett. Ez az eredmény az egyik legrosszabb a vizsgált országok között: csak Ukrajna, Bulgária, Oroszország és Görögország esetében látunk még ennél is kedvezőtlenebb 
4. táblázat: Veszélyeztetettek aránya az egyes országokban (\%)

Vulnerable people in various countries (\%)

$\begin{array}{cccccc}\text { rizzkal } & \text { Lelkl } & \text { Iarsas } & \text { szubjektiv } & \text { Kompozıt } & \text { Kompozıt tnalkator } \\ \text { egészség } & \text { egészség } & \text { kapcsolatok } & \text { anyagi } & \text { indikátor } & 95 \% \text {-oskonfidencia }\end{array}$

\begin{tabular}{|c|c|c|c|c|c|c|c|}
\hline \multirow[b]{2}{*}{ Ukrajna } & \multirow[b]{2}{*}{15,4} & \multirow[b]{2}{*}{27,0} & \multicolumn{3}{|c|}{ helyzet } & \multicolumn{2}{|c|}{ intervalluma } \\
\hline & & & 2,0 & 73,5 & 78,9 & 77,6 & 80,1 \\
\hline Bulgária & 11,1 & 33,2 & 1,6 & 72,8 & 76,5 & 75,2 & 77,7 \\
\hline Görögország & 5,2 & 22,3 & 5,4 & 65,8 & 70,9 & 69,2 & 72,6 \\
\hline Oroszország & 13,0 & 20,4 & 3,9 & 54,6 & 65,0 & 63,9 & 66,1 \\
\hline Magyarország & 13,4 & 18,3 & 8,4 & 45,3 & 54,9 & 53,7 & 56,0 \\
\hline Litvánia & 10,3 & 19,6 & 3,2 & 36,5 & 48,7 & 47,7 & 49,9 \\
\hline Ciprus & 5,6 & 7,8 & 4,4 & 42,9 & 48,3 & 46,2 & 50,4 \\
\hline Szlovákia & 8,2 & 10,4 & 1,8 & 41,4 & 47,4 & 45,9 & 49,0 \\
\hline Portugália & 10,9 & 11,4 & 0,9 & 39,3 & 46,8 & 45,6 & 48,0 \\
\hline Izrael & 7,8 & 5,8 & 2,0 & 34,3 & 45,8 & 44,8 & 46,7 \\
\hline Csehország & 8,2 & 10,5 & 1,7 & 35,0 & 42,7 & 41,7 & 43,7 \\
\hline Horvátország & 13,6 & 14,4 & 0,7 & 27,4 & 38,7 & 36,3 & 41,1 \\
\hline Olaszország & 6,2 & 8,8 & 2,9 & 30,4 & 38,6 & 37,0 & 40,2 \\
\hline Észtország & 10,5 & 10,7 & 1,5 & 29,1 & 36,3 & 35,2 & 37,3 \\
\hline Lengyelország & 9,4 & 8,0 & 2,8 & 26,7 & 35,1 & 34,0 & 36,2 \\
\hline Spanyolország & 10,5 & 5,6 & 1,6 & 25,8 & 34,4 & 33,3 & 35,4 \\
\hline Írország & 2,6 & 8,3 & 1,9 & 25,6 & 32,6 & 31,7 & 33,5 \\
\hline Franciaország & 7,6 & 9,7 & 1,5 & 18,2 & 27,1 & 26,1 & 28,1 \\
\hline $\begin{array}{l}\text { Egyesült } \\
\text { Királyság }\end{array}$ & 7,2 & 7,0 & 2,0 & 17,0 & 26,7 & 25,7 & 27,6 \\
\hline Szlovénia & 8,7 & 8,4 & 1,8 & 16 & 26,5 & 25,3 & 27,7 \\
\hline Belgium & 5,1 & 3,7 & 1,4 & 22,1 & 26,1 & 25,1 & 27,1 \\
\hline Németország & 10 & 6,1 & 1,2 & 13,1 & 23,0 & 22,2 & 23,7 \\
\hline Ausztria & 4,1 & 5,8 & 1,2 & 13,5 & 20,0 & 18,1 & 21,2 \\
\hline Finnország & 4,8 & 2,5 & 0,2 & 14 & 18,7 & 17,8 & 19,5 \\
\hline Izland & 4,5 & 2,4 & 0,4 & 12,5 & 17,9 & 16,0 & 19,8 \\
\hline Hollandia & 4,3 & 2,0 & 0,3 & 11,0 & 15,9 & 15,1 & 16,7 \\
\hline Svájc & 3,0 & 2,5 & 0,5 & 11,4 & 15,1 & 14,2 & 16,0 \\
\hline Svédország & 4,2 & 3,2 & 0,3 & 9,5 & 15,0 & 14,1 & 15,9 \\
\hline Norvégia & 6,0 & 2,8 & 0,5 & 7,3 & 13,5 & 12,6 & 14,3 \\
\hline Dánia & 6,1 & 2,0 & 0,3 & 6,0 & 12,8 & 11,8 & 13,7 \\
\hline
\end{tabular}

Megjegyzés: a számítások post-stratification súlyok használatával történtek Forrás: szerzői szerkesztés az ESS 5-8 hullámok adatelemzése alapján 
képet. Másrészt egyértelmű az adatokat olvasva az is, hogy a sorrend másik végén főként skandináv országokat találunk Svájccal és Hollandiával egyetemben.

A tanulmány utolsó lépéseként a fenti országok közül kiválasztunk néhányat, ahol rendkívül magas a veszélyeztetettek aránya, illetve ahol éppen ellenkezőleg, meglehetősen alacsony. Esetükben komparatív módon azt fogjuk megvizsgálni, hogy mi mondható el általában az adott országok bizalomkultúrájáról, egész pontosan a már ismertetett bizalomtartalmak makroszintű átlagértékeiről, továbbá megnézzük azt is: a veszélyeztetettek és a nem-veszélyeztetettek körében, országonként, mit tapasztalunk a bizalomtartalmak átlagértékeinek alakulása vonatkozásában (5. táblázat).

Az 5. táblázat adatai szerint azokban az országokban, ahol jelentős arányban vannak veszélyeztetettek, ott nagyobb mértékủ a bizalmatlanság társadalmi szinten. Ha külön-külön vizsgáljuk az egyes bizalomtartalmakat, akkor az látható, hogy az emberek egymásról alkotott percepciói (embertársi viszonyrendszerek) egyértelműen kedvezőbbek az alacsony veszélyeztetettségü országokban, s ugyanez elmondható a politikai-közéleti részvételi hajlandóságról és aktivitásról, valamint a melegek és leszbikusok elfogadásáról is. Egyedül a migráció megítélése vonatkozásában nem válnak el egyértelműen a kedvező és kedvezőtlen veszélyeztetettségű országok eredményei, noha az orosz és különösen a magyar adatok kiugró idegenellenességről árulkodnak, miközben a svéd adat ellenkezőleg: rendkívüli befogadáskészséget sugall.

Összefoglalóan kijelenthető: a bizalomtartalmak kapcsán tapasztalható különbségek veszélyeztetettek és nem-veszélyeztetettek között mind az alacsony, mind a magas veszélyeztetettségi arányú országokban inkább jelentősek, amennyiben a veszélyeztetettek mindenütt bizalmatlanabbak nem-veszélyeztetett honfitársaikhoz képest. (Az egyes bizalomtartalmak mentén országonként futtatott varianciaanalízisek a legtöbb esetben szignifikáns eltérést mutatnak a veszélyeztetettek és a nem-veszélyeztetettek csoportjai között.)

\section{Összefoglalás}

A tanulmány következtetéseként három megállapítást ajánlunk rögzíteni: (1) egyéni szinten először is alátámasztást nyert, hogy akik fizikai egészségüket, lelki egészségüket, társas kapcsolataikat és/vagy szubjektív anyagi helyzetüket tekintve veszélyeztetettek, azok bizalmatlanabbak. (2) A legutolsó táblázat adataiból világosan kiderült egy lényeges makroszintű összefüggés, miszerint azon országokban, ahol többen veszélyeztetettek a fenti dimenziók alapján, ott nagyobb a társadalmi szintű bizalmatlanság (az egyes bizalomtartalmak átlagértékei alacsonyabbak). (3) Azon országokban, ahol inkább a bizalmatlanság kultúrája müködik, ott a nem-veszélyeztetettek is bizalmatlanabbak (tehát érvényesül a kulturális hatás). Mindez a tanulmány bevezetőjében elhangzott gondolathoz 


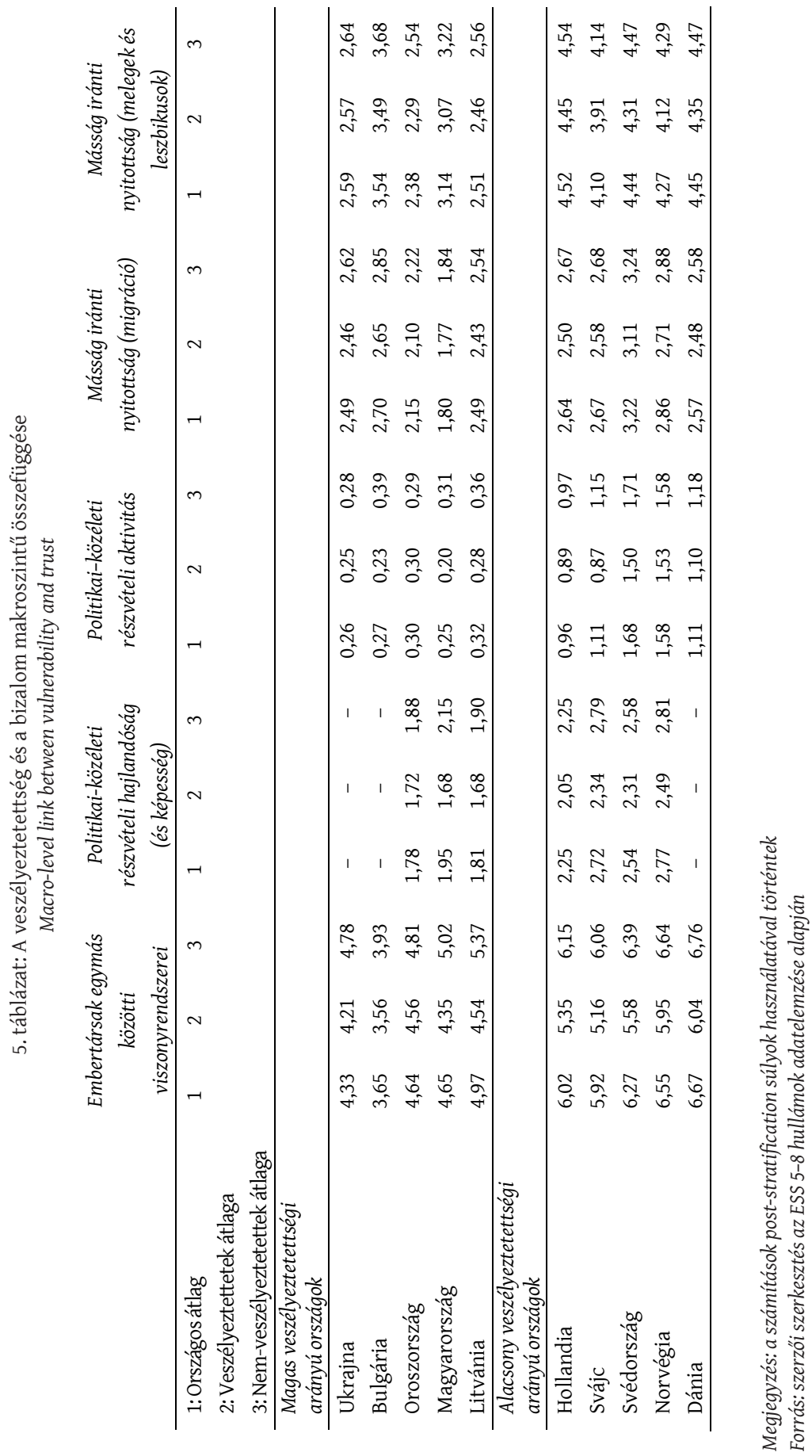


visszakapcsolva azt jelentheti (s ennek vizsgálata csak idővel lesz elvégezhető): ahol jelentős arányban vannak veszélyeztetettek, ott a válságon való felülkerekedés lassabbnak és nehézkesebbnek ígérkezik, mivel hiányzik az embereket összekapcsoló bizalom. Ez utóbbi feltételezéssel való foglalkozás Magyarországra vonatkozóan annyiban mindenképpen releváns, hogy idehaza jelentős arányban vannak fizikai és lelki egészségüket, társas kapcsolataikat, valamint szubjektív anyagi helyzetüket tekintve veszélyeztetettek, miközben a magyar társadalmi kultúra erősen bizalomhiányos. Jelen tanulmányban - a mikro- és makroaspektusok hatásmechanizmusainak részletező kielemzése nélkül - ezen alapprobléma feltárására koncentráltunk.

\section{Köszönetnyilvánítás}

A szerzők kutatását az Innovációs és Technológiai Minisztérium Felsőoktatási Intézményi Kiválósági Programja finanszírozta, a Pécsi Tudományegyetem 4. - A hazai vállalatok szerepének növelése a nemzet újraiparosításában - tématerületi programja keretében.

\section{Irodalom}

Albert F., Dávid B. (2020a): Nem csoda, hogy az idősek nehezen maradnak otthon a járvány idején. Qubit, 2020. április 15. https://szociologia.tk.mta.hu/hirek/2020/04/covid-kutatasok-hirek (Letöltve: 2020. 06. 02.)

Albert F., Dávid B. (2020b): Vigyázzunk, nehogy a távolságtartás elszigetelődéshez vezessen! Qubit, 2020. március 26. https://szociologia.tk.mta.hu/hirek/2020/04/covid-kutatasok-hirek (Letöltve: 2020.06 .02$.

Bodor, Á., Grünhut Z. (2015): Társadalmi rétegződés Magyarországon a bizalom mentén. Századvég, 78., 19-47.

Brons, L. (2015): Othering. An Analysis. Transcience, 1., 69-90. http://doi.org/d4gx

Cavell, S. (1976): Must We Mean What We Say? Cambridge University Press, Cambridge

Csizmadia P., Illéssy M. (2020): A nagy leállás: a magyar munkahelyek közel fele került veszélybe. TK Szociológiai Intézet https://szociologia.tk.mta.hu/hirek/2020/04/covid-kutatasok-hirek (Letöltve: 2020.06.02.)

Ferencz Z. (2020): Miért okoz nehézséget a korlátozó intézkedések betartása? TK Szociológiai Intézet https://szociologia.tk.mta.hu/hirek/2020/04/covid-kutatasok-hirek (Letöltve: 2020. 06. 02.)

Giddens, A. (1984): The Constitution of Society. Outline of the Theory of Structuration. Polity, Cambridge

Grünhut Z., Kömüves D., Bodor Á. (2019a): A bizalomelmélet kritikai újragondolása az eldologiasodás szempontjából. Replika, 113., 11-24. http://doi.org/d4gz

Grünhut Z., Bodor Á., Hegedűs M. (2019b): A bizalom morális-emocionális és racionális igazolásainak empirikus vizsgálati lehetőségei. Replika, 113., 25-43. http://doi.org/d4g2

Haybron, D. M. (2013): Happiness: A Very Short Introduction. Oxford University Press, New York. http:// doi.org/d4g3

Haybron, D. M. (2000): Two philosophical problems in the study of happiness. The Journal of Happiness Studies, 2., 207-225. http://doi.org/bnxn4j

Honneth, A. (2007): Reification: A Recognition-theoretical View. Oxford University, Oxford

Jaeggi, R. (2014): Alienation. Columbia University, New York http://doi.org/d4g4

Kekes, J. (1988): The Examined Life. Bucknell University Press, Lewisburg 
Messing V., Ságvári B. (2020): A járvány miatt sokaknak bezárult a világ - Hazai vizsgálat a 65 év felettiek helyzetéről. Qubit, 2020. április 1. https://szociologia.tk.mta.hu/hirek/2020/04/covid-kutatasok-hirek (Letöltve: 2020. 06. 02.)

Messing V., Ságvári B., Hammer G. (2020): Jövedelmi helyzet és az alapjövedelem támogatottsága Európában és Magyarországon. TK Szociológiai Intézet https://szociologia.tk.mta.hu/hirek/ 2020/04/covid-kutatasok-hirek (Letöltve: 2020. 06.02.)

Nozick, R. (1989): The Examined Life: Philosophical Meditations. Simon and Schuster, New York

Sulitzeanu-Kenan, R., Halperin, E. (2013): Making a difference: Political efficacy and policy preference construction. British Journal of Political Science, 2., 295-322. http://doi.org/f4rnff

Sztompka, P. (1999): Trust: A Sociological Theory. Cambridge University Press, Cambridge

Uslaner, E. M. (2002): The Moral Foundations of Trust. Cambridge University Press, Cambridge 